ENTREPRENEURSHIP AND SUSTAINABILITY ISSUES

ISSN 2345-0282 (online) http://jssidoi.org/jesi/

2021 Volume 8 Number 4 (June)

http://doi.org/10.9770/jesi.2021.8.4(25)

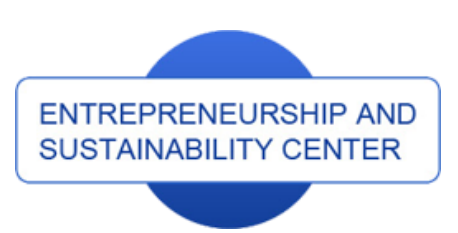

Publisher

http://jssidoi.org/esc/home
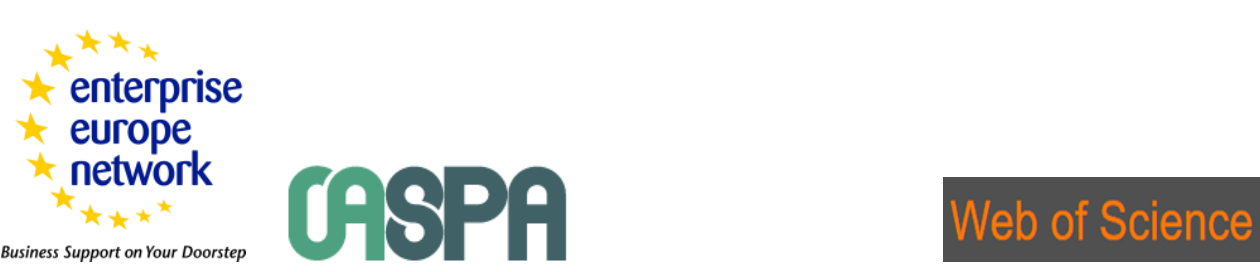

rest/issidoi. org/esc/home

Business Support on Your Doorstep

.

\title{
FACTORS INFLUENCING WAYS OF ORGANISING LIFE IN OLD AGE IN THE CONTEXT OF SOCIAL EXCLUSION RISK. THE CASE OF POLAND
}

\author{
Monika Adamczyk \\ Institute of Sociological Sciences, The John Paul II Catholic University of Lublin, Al. Rackawickie 14, 20-950 Lublin, Poland \\ E-mail: $\underline{\text { mdadamczyk@kul.pl }}$
}

Received 20 November 2020; accepted 10 April 2020; published 30 June 2021

\begin{abstract}
Strategies of organizing one's life in old age are a broad topic, involving the material-economic, social and psychological aspects. In its fundamental meaning, it refers primarily to everyday activities such as personal care and getting around, as well as social roles such as interpersonal relationships and relaxation. Although the constraints to the participation in normal ageing are well-known, little research has been devoted to planned old-age life organization strategies employed with the view to alleviating the constraints and counteracting social exclusion of elderly people which may be a consequence of a disruption of social participation. The aim of the present paper is to examine the relationships between socio-demographical variables such as age and sex and preferred old-age organization strategies. The research was conducted by means of a diagnostic survey (face-to-face interviews) with the use of the computer assisted interview questionnaire technique. CAPI interviews (Computer Assisted Personal Interview) were carried out in respondents' homes on a nationwide random sample of households - 1006 people aged 15 and over. The sampling frame was the PESEL. A six-item original scale was introduced in order to identify the coping strategies in old age. Statistical analysis was performed using the non-parametric tau-Kendall correlation coefficient with the view to assessing the relationship between socio-demographical variables such as age and gender and oldage life organization strategies. The results: Irrespective of the respondent's age and of their gender, adult Poles definitely preferred old-age life organization strategies consisting in remaining in their own flat and using the natural support system based on a primary network that is bonds with children, the spouse and extended family. Statistical analysis showed a lack of relationship between coping strategies and age and gender. Age and gender do not co-occur with the choice of life organisation strategies in old age.
\end{abstract}

Keywords: elderly people; social exclusion; social support; sustainable development

Reference to this paper should be made as follows: Adamczyk, M. 2021. Factors influencing ways of organising life in old age in the context of social exclusion risk. The case of Poland. Entrepreneurship and Sustainability Issues, 8(4), 418-430.

http://doi.org/10.9770/jesi.2021.8.4(25)

JEL Classifications: A14, B55

Additional disciplines: sociology 


\section{ENTREPRENEURSHIP AND SUSTAINABILITY ISSUES}

ISSN 2345-0282 (online) http://jssidoi.org/jesi/

2021 Volume 8 Number 4 (June)

http://doi.org/10.9770/jesi.2021.8.4(25)

\section{Introduction}

The number of elderly people requiring care is predicted to at least double over the next years. The worrying fact is that governments of numerous countries have difficulty ensuring high quality care to people with limited functional and cognitive capacities. As prognoses indicate, in the year 2050 there will be more than double the number of people over 80 than now, developed countries will deal with a progressive process of double ageing. The percentage of people of this age group in the general population will increase from $3.9 \%$ in 2010 to $10 \%$ in 2050 in OECD countries and from $4.7 \%$ to $11.3 \%$ in $26 \mathrm{EU}$ member countries and Great Britain (OECD, 2021). It is estimated that even half of them will need assistance in their everyday lives, therefore it is of great importance to identify problems of people experiencing their old age today as well as to learn the opinion on organizing their lives in this phase of the people who have not yet crossed the conventional threshold of old age. The threshold of old age adopted in the present paper is turning 60. Adopting this threshold is associated primarily with the definition of an elderly person adopted in the Polish official statistics according to which the elderly are people aged 65 and over or 60 and over. The adoption of such a definition is connected with the fact that the retirement age for men and women is not the same. Most commonly, the uniform age of 60 or 65 is adopted or a separate age is introduced for men (65) and for women (60). UN studies apply a uniform age of 65 for men and women (World Report on Ageing and Health 2015). The cultural, social and economic 'borders' of old age are becoming blurred, shifting the phase of late adulthood and old age proper into the depths of human life - 50-75 years and over 75 years respectively (Garfein, Herzog, Robust 1995; Hellström, Andersson, Hallberg, 2004; Adamczyk, 2019). As human life expectancy increases and, consequently, the threshold for retirement is pushed back, it may not be long before other measures are introduced to serve demographers and economists.

One needs to redefine old age in its social dimension and to identify strategies of coping with potential problems appearing in this phase of life (Avers, 2020; Aspalter, 2020; Ribeiro, Silva Borges, Cavalcanti Ferreira de Araujo, Santos Souza, 2017). This is important for several reasons. Firstly, ageing is not necessarily associated with a decline in mental and physical performance or withdrawal from social roles. This has been confirmed by numerous studies on human development across the life course (Baltes, Baltes, 1990; Fernández-Ballesteros et al., 2010). Secondly, as written earlier, according to WHO estimates, between 2000 and 2050 the population of people aged 60 and over will triple (from 600 million to 2 billion). The problem of ageing societies affects all countries, but is most pronounced in underdeveloped countries, where the number of elderly people will increase from 400 million in 2000 to 1.7 billion in 2050. This demographic shift will have a significant impact on public health and welfare systems (World Report on Ageing and Health 2015). Thirdly, people who, because of their state of health, are forced to rely on long-term care should be provided with such a possibility in the form of an institutional infrastructure as well as qualified staff. The quality of long-term care in old age is important for three reasons. Firstly, users of care services are demanding more voice and control over their lives, which means that they are becoming informed consumers of care services. Secondly, as the cost of care services continues to rise from $1.6 \%$ of GDP in OECD countries to at least double that by 2050 - long-term care services are under pressure to improve their accountability. Thirdly, governments have a responsibility to protect vulnerable older people from potential abuse and age-based social exclusion (OECD, 2013).

\section{Social exclusion - the development of the conception}

The concept of social exclusion has evolved over time and adapted to national contexts (Daly, Silver, 2009; Betlej, 2017; Čižo et al., 2020; Fedulova et al., 2019; Lankauskienè et al., 2012; Betlej, 2019). Although it is linked to the concept of poverty, it emphasises the dynamics of social maladaptation or social disqualification (Silver, 2019). In the European Union, the discourse on social exclusion has been ongoing since the 1970s, successive years have brought new resolutions and solutions to combat social exclusion (1989 resolution on combating social exclusion (Publications Office of the EU, 1989), a commitment also included in the Amsterdam Treaty of 1997. As a result of the Lisbon process, economic and social policies were combined under the 


\section{ENTREPRENEURSHIP AND SUSTAINABILITY ISSUES}

ISSN 2345-0282 (online) http://jssidoi.org/jesi/

2021 Volume 8 Number 4 (June)

http://doi.org/10.9770/jesi.2021.8.4(25)

European 'social model.' In order to act more effectively and monitor changes in social exclusion, the Member States agreed in 2001 on a set of common objectives and 18 social indicators designed to facilitate a voluntary, open and, importantly, effective method of coordination between different national social policies. Most indicators relate to income and employment; a few relate to health and education, but these are still evolving. Progress in the area of social exclusion over the years has not been satisfactory, and in order to increase the effectiveness of actions, the European Year for Combating Poverty and Social Exclusion was declared and the EU introduced Agenda 2020, in which social inclusion was one of the five objectives. The European Platform against Poverty and Social Exclusion set a headline target of reducing the number of people at risk of poverty and social exclusion by 20 million (Silver, 2019). It is common to equate the conception of social exclusion with poverty, social inequality, and marginalisation and discrimination or the emergence of an underclass within the social structure (Hickey, du Toit, 2007). This is a simplified approach, as poverty itself may not be a cause but rather an effect of exclusion, and defining social exclusion is often linked to the perspective of discipline, context and even political efforts to counteract disadvantage (Silver 1995; Smirnov A. et al., 2019).

The concept of social exclusion is present in several theoretical traditions. The first approach is associated with French sociology and emphasises the dynamic and processual nature of exclusion in its relational, symbolic and economic dimensions. It is referred to in the literature as the solidarity paradigm (Silver, 1994: 550-555). A crucial assumption is linked to the discourse on 'solidarity', the 'social contract.' Concern is expressed about the weakening or breaking of the social bond, which introduces risks for the individual in terms of 'material and symbolic exchange with the larger society' (Silver 1995: 66-67). The second approach, identified by Silver as the monopoly paradigm, is related to the conception of social exclusion present in the Anglo-Saxon tradition. This approach emerged from critical social policy and debates about disadvantage. The Anglo-Saxon perspective emphasised considerations of civil rights, opportunities for full participation in society and power imbalances resulting from obligatory, hierarchical social structures (Silver 1994: 561-569). A third approach called the specialisation paradigm is associated with American and British discourse. In this paradigm, liberal ideologies emphasise concepts of contractual and voluntary exchange of rights and responsibilities, where individual differences lead to specialisation in competitive spheres involving the market and social groups. Exclusion is perceived as a product of discrimination, lack of enforcement or inadequate enforcement of rights by the liberal state, barriers to movement/exchange between spheres and market failures (Silver, 1994: 555-561).

Social exclusion can take the form of controlling access to space as well as to activities, resources and information. In his classic essays on 'The Stranger' and 'The Social Frontier', Simmel gave rise to considerations of 'social distance.' The extent and persistence of spatial segregation within a group often reflects its social distance or marginality from the mainstream. However, as Simmel noted, people can be physically close, as in a metropolis, but not socially close (Simmel, 2006: 204-212). Adopting this perspective is very important in the context of factors that influence the risk of social exclusion of older people. According to WHO estimates, between 2000 and 2050 the population of people aged 60 and over will triple (from 600 million to 2 billion).

This paper assumes an approach that sees social exclusion as a particular form of rupture of social ties, a fracture in the social fabric and a deficit of solidarity (Silver, 2008). The adoption of the solidarity paradigm in analyses of social exclusion is related to the specific research problem of coping strategies in old age. This perspective also allows one to understand that the individual's coping strategy in old age may determine whether or not they will be subject to exclusion based on breaking ties with the family, the environment. Older people are a group particularly prone to social exclusion, however - which also applies to Polish pensioners - not because of the threat of poverty. The economic situation of older Poles is surprisingly good compared to other European countries since only a few percent of them are at risk of poverty (The Social Situation in the European Union 2007, 2008, 2009; Social Situation Monitor - Research findings 2020). When drawing conclusions, however, one should bear in mind the very large differences in income and living standards between the societies of individual countries. 


\section{ENTREPRENEURSHIP AND SUSTAINABILITY ISSUES}

ISSN 2345-0282 (online) http://jssidoi.org/jesi/

2021 Volume 8 Number 4 (June)

http://doi.org/10.9770/jesi.2021.8.4(25)

\section{Research Methodology}

\subsection{Method}

The aim of the research was to identify strategies for coping with problematic situations in old age in the context of social exclusion risk. The research problem posed in the article does not focus on social exclusion conceived of as the threat of poverty, but captures this phenomenon as a form of rupture of social ties, rupture of the social fabric and solidarity deficit. In this context, the research aimed to identify factors associated with particular coping strategies for potential problematic situations that may occur in old age. In order to identify coping strategies in old age, 1006 adult Poles were surveyed. The research was carried out by means of a diagnostic survey (face-to-face interviews) using a computer-assisted interview questionnaire technique. CAPI (Computer Assisted Personal Interview) interviews were conducted at the respondents' homes on a nationwide random sample of households. The sampling frame was PESEL. With the view to identifying coping strategies in old age, an original six-point scale was employed. The application of such a research technique was aimed at determining the preferences of adult Poles regarding the forms of organisation of their life in old age, as well as at discovering the conditions for the choices made.

\subsection{Participants}

The study involved 1006 adult Poles aged 15 and over, in order to identify groups of respondents according to the life phase they are in, variables were recoded and four age groups were created corresponding in some respects to the life phases proposed by Daniel J. Levinson (Levinson, 1959, 1977,1978). Adopting this division created four groups: people aged 15-20 accounted for 7.1\% of all study subjects (71), people aged 21-40 33.4\% of all study subjects (336), people aged 41-59 30.2\% of study subjects (304) and people aged 60 years and over $29.3 \%$ of all study subjects (295). The gender distribution of the survey population was as follows: (485) $48.2 \%$ of survey respondents were male and (521) $51.8 \%$ were female.

\subsection{Tools}

In order to identify which, in the opinion of the respondents, are the best strategies for organising life in old age, a proprietary tool was used in the form of a scale consisting of five statements to which the participant had to respond on a scale from one to six. Description of the scale: The scale consisted of statements which concerned the ways of organising life in old age and the extent to which the given strategies satisfy the needs of the elderly: living in one's own flat and using temporary help from people close to oneself - family, friends, neighbours; living in one's own flat, with the help of third persons, e.g. a carer for the elderly; sharing one's own flat with the help of third persons, e.g. a carer for the elderly; sharing the home with children, grandchildren or extended family; living together with other older people, e.g. in a nursing home, a rest home; living in one's own home with the support of day care centres.

\section{Results}

In order to determine the most frequently selected strategies of organising one's life in old age, so as to cope with problems that may occur in this life period, the author's measurement scale was employed, referring to five possible ways of organising one's life (living in one's own flat and using temporary help of people close to oneself - family, friends, neighbours; living in one's own flat, having the assistance of third persons, e.g. a carer of an elderly person; sharing a flat with one's children, grandchildren or extended family; living together with other older people e.g. in a nursing home, a rest home; living in their own flat with support of day care centres). Respondents were asked to rate the extent to which individual strategies meet the needs of older people on a scale of one to six, where 1 meant do not meet the needs of older people at all and 6 meant do not know/hard to say. 
ENTREPRENEURSHIP AND SUSTAINABILITY ISSUES

ISSN 2345-0282 (online) http://jssidoi.org/jesi/

2021 Volume 8 Number 4 (June)

http://doi.org/10.9770/jesi.2021.8.4(25)

The analysis of source materials shows that in Poland, the elderly can rely primarily on the help of their immediate family (Błędowski, Szatur-Jaworska, Szwed-Lewandowska, Kubicki, 2012, p.101; Błędowski, SzaturJaworska, 2017, pp.36-40). There is also a clearly marked neighbourhood solidarity. Acquaintances and friends are less likely to provide support to the elderly, while assistance from institutions established to provide it is by far the least frequent. The analysis of the data shows that the most popular strategies of organising one's life in old age are those which include living in one's own flat and taking advantage of social support from the closest family. For $55.3 \%$ of all respondents, it is living in their own flat and possibly using the support of the closest people: family, friends that is the best strategy. Equally popular is the strategy of living in one's own flat and using the assistance of supportive persons (50.4\%). The least popular strategy to organise one's life in old age among respondents is to live with other elderly people in institutions dedicated to elderly people such as Social Assistance Homes, Rest Homes. A total of $28 \%$ of respondents think that these types of institutions do not satisfy or satisfy to a very little extent the needs of older people.

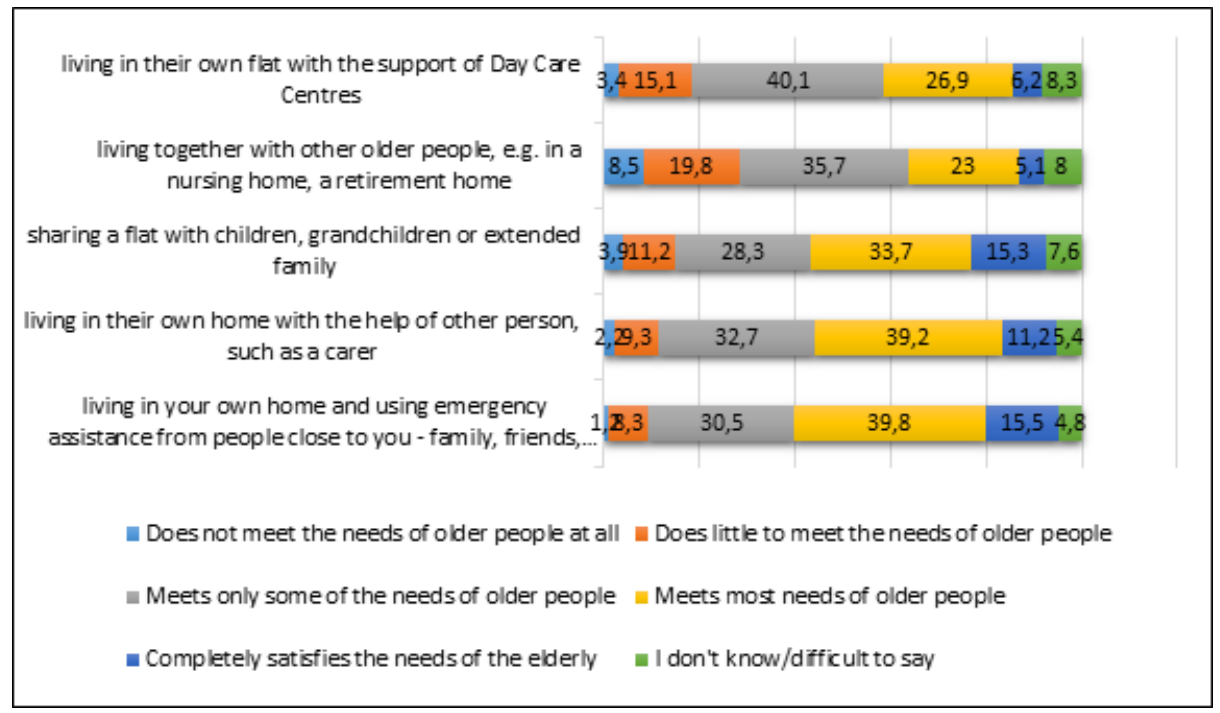

Figure 1. Strategies for organising one's life in old age in $\%(\mathrm{~N}=1006)$ Source: Own study

The adoption of a social support formula based on strong family and friendship ties is strongly associated with the possibility of counteracting social exclusion consisting in breaking the ties with the family, neighbourhood or friendship environment. This structural social support, distinguished from other networks by the fact of the existence of social contacts, ties, affiliation and performing the function of helping people in difficult situations (Sęk, 2004), seems to be a very popular strategy for organising life in old age. The figure 2 below shows how the strength of ties, contacts and affiliations is distributed depending on the entities associated with the elderly person; the closer to this person, the stronger the ties. 
ENTREPRENEURSHIP AND SUSTAINABILITY ISSUES

ISSN 2345-0282 (online) http://jssidoi.org/jesi/

2021 Volume 8 Number 4 (June)

http://doi.org/10.9770/jesi.2021.8.4(25)

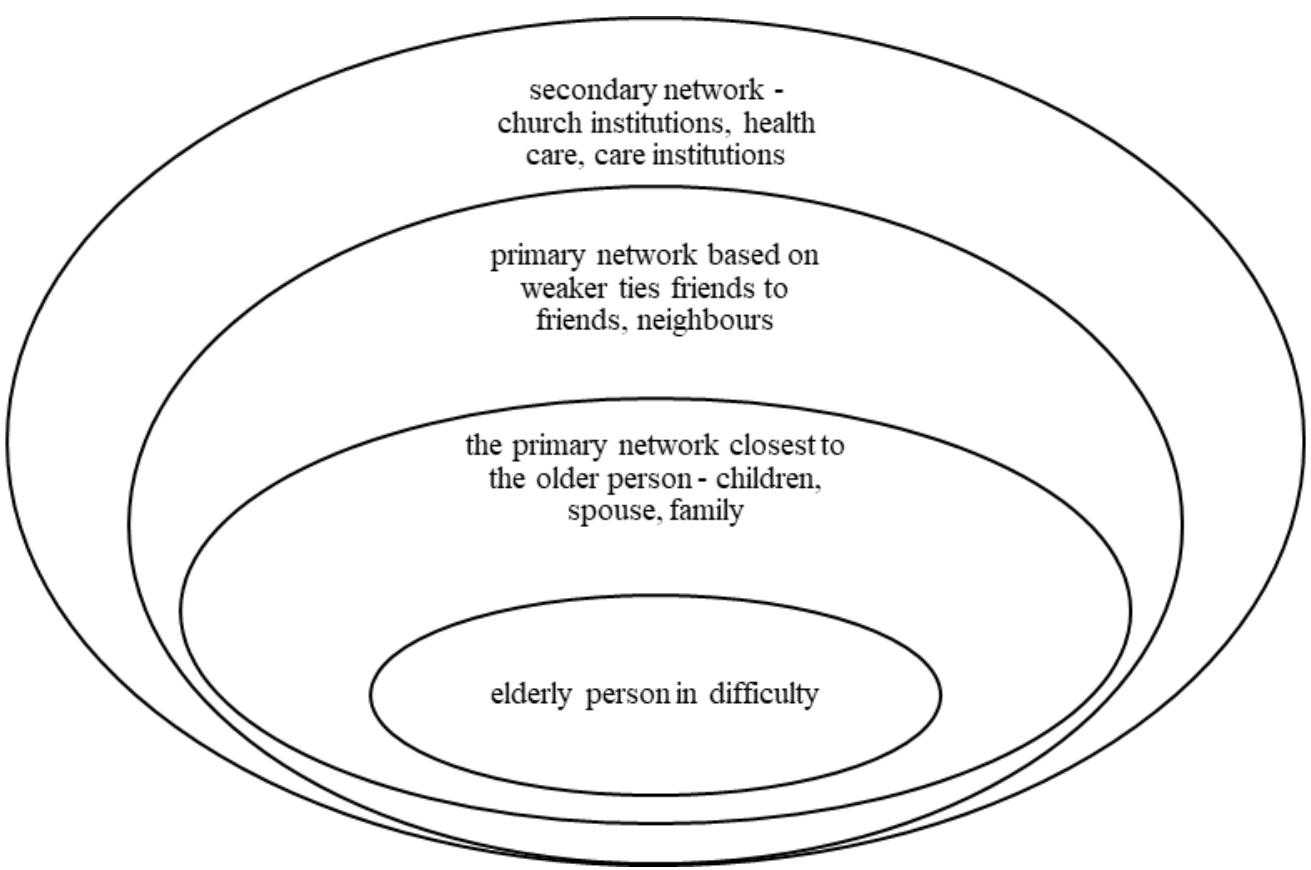

Figure 2. Diagram of the strength of the relationship between the older person and the environment Source: Own study

Another point of the research was to define factors conditioning the adoption of a particular strategy of organising life in old age. The study assumed that age is one of the important factors influencing which strategy is considered to be good in meeting the needs of older people. It was presumed that the support for strategies based on living in one's own flat and using the support of family and relatives would increase with age. This assumption was based on the analysis of source data, according to which in Poland, in most cases, it is the family that provides informal care services to seniors. Care within the family for an elderly person is very often perceived as an obligation resulting from the fact that parents or grandparents devoted both financial and time resources at earlier stages of their lives to the younger generation (Błędowski, Szatur-Jaworska, Szwed-Lewandowska, Kubicki, 2012, p.101; Błędowski, Szatur-Jaworska, 2017, 36-40). The results of the conducted research confirmed this assumption. Clearly, the strategy of organising life in old age consisting in living in one's own flat and using temporary support from family or friends gains importance with age. It appears that as one moves into older age groups, the strategy of organising one's life in old age assuming social support, referring to temporary help from loved ones and relying on living in one's own flat gains in importance. For almost $60 \%$ of the respondents aged 60 and over, this is the strategy that fully or mostly satisfies the needs of older people. More than half (53.9\%) of respondents in the 41-59 age group believe similarly. A detailed breakdown of the data is presented in the table 1 below. 
Table 1. The way of organising life in old age: living in own flat and using temporary help of close people - family, friends, neighbours, by age groups in $\%$.

\begin{tabular}{l} 
Does the following way of organising old age meet the needs of older people: living in your own flat and using temporary help from \\
relatives - family, friends, neighbours? \\
\hline
\end{tabular}

Source: Own study

Similarly, the strategy based on independent living and the use of temporary support from third persons is assessed in a positive light. Moving from the youngest age group to the increasingly elderly, there is a rise in support for this strategy of organising life in old age. It is considered to completely satisfy and to satisfy most of the needs of older people by respectively $46.5 \%$ of those aged $15-20,51.5 \%$ of those aged $21-40,49.7 \%$ of those aged $41-59$ and $50.9 \%$ of those aged 60 and over. A similar relationship can be observed in the case of living together with children, grandchildren or extended family. Detailed data distribution is presented in the table 2 below.

Table 2. Way of organising life in old age, according to age groups in \%

\begin{tabular}{|c|c|c|c|c|c|c|c|}
\hline \multicolumn{8}{|c|}{ Does the following way of organising life in old age meet the needs of older people? } \\
\hline & $\begin{array}{c}\text { Does not } \\
\text { satisfy } \\
\text { elderly } \\
\text { people's } \\
\text { needs at all }\end{array}$ & $\begin{array}{c}\text { Satisfies } \\
\text { elderly } \\
\text { people's } \\
\text { needs to a } \\
\text { little extent }\end{array}$ & $\begin{array}{c}\text { Satisfies only } \\
\text { some elderly } \\
\text { people's } \\
\text { needs }\end{array}$ & $\begin{array}{c}\text { Satisfies } \\
\text { most elderly } \\
\text { people's } \\
\text { needs }\end{array}$ & $\begin{array}{c}\text { Fully } \\
\text { satisfies } \\
\text { elderly } \\
\text { people's } \\
\text { needs }\end{array}$ & $\begin{array}{c}\text { Don't } \\
\text { know/hard to } \\
\text { say }\end{array}$ & Total \\
\hline $15-20$ & $5.6 \%$ & $12.7 \%$ & $21.1 \%$ & $35.2 \%$ & $11.3 \%$ & $14.1 \%$ & $100 \%$ \\
\hline $21-40$ & $2.1 \%$ & $8.9 \%$ & $29.8 \%$ & $40.5 \%$ & $11.0 \%$ & $7.7 \%$ & $100 \%$ \\
\hline $41-59$ & $1.0 \%$ & $9.2 \%$ & $37.5 \%$ & $40.5 \%$ & $9.2 \%$ & $2.6 \%$ & $100 \%$ \\
\hline 60 and over & $2.7 \%$ & $9.2 \%$ & $33.9 \%$ & $37.3 \%$ & $13.6 \%$ & $3.4 \%$ & $100 \%$ \\
\hline $21-40$ & $3.3 \%$ & $10.4 \%$ & $29.2 \%$ & $31.5 \%$ & $16.4 \%$ & $9.2 \%$ & $100 \%$ \\
\hline $41-59$ & $4.3 \%$ & $11.5 \%$ & $29.6 \%$ & $35.9 \%$ & $12.5 \%$ & $6.3 \%$ & $100 \%$ \\
\hline 60 and over & $4.4 \%$ & $10.5 \%$ & $26.1 \%$ & $35.3 \%$ & $17.3 \%$ & $6.4 \%$ & $100 \%$ \\
\hline
\end{tabular}


ENTREPRENEURSHIP AND SUSTAINABILITY ISSUES

ISSN 2345-0282 (online) http://jssidoi.org/jesi/

2021 Volume 8 Number 4 (June)

http://doi.org/10.9770/jesi.2021.8.4(25)

\begin{tabular}{|l|l|l|l|l|l|l|l|}
\hline \multicolumn{7}{|c|}{ living in their own flat with the support of day care centres } \\
\hline $15-20$ & $2.8 \%$ & $15.5 \%$ & $33.8 \%$ & $26.8 \%$ & $4.2 \%$ & $16.9 \%$ & $100 \%$ \\
\hline $21-40$ & $3.0 \%$ & $13.4 \%$ & $39.3 \%$ & $27.1 \%$ & $7.7 \%$ & $9.5 \%$ & $100 \%$ \\
\hline $41-59$ & $3.9 \%$ & $16.4 \%$ & $42.1 \%$ & $25.0 \%$ & $5.3 \%$ & $7.2 \%$ & $100 \%$ \\
\hline 60 and over & $3.4 \%$ & $15.6 \%$ & $40.3 \%$ & $28.8 \%$ & $5.8 \%$ & $6.1 \%$ & $100 \%$ \\
\hline \multicolumn{7}{|c|}{ living together with other older people, e.g. in a nursing home, a retirement home } \\
\hline $15-20$ & $4.2 \%$ & $21.1 \%$ & $31.0 \%$ & $29.6 \%$ & $0.0 \%$ & $14.1 \%$ & $100 \%$ \\
\hline $21-40$ & $8.3 \%$ & $18.8 \%$ & $33.0 \%$ & $23.2 \%$ & $6.8 \%$ & $9.8 \%$ & $100 \%$ \\
\hline $41-59$ & $8.6 \%$ & $21.1 \%$ & $36.2 \%$ & $22.7 \%$ & $4.6 \%$ & $6.9 \%$ & $100 \%$ \\
\hline 60 and over & $9.8 \%$ & $19.3 \%$ & $39.3 \%$ & $21.4 \%$ & $4.7 \%$ & $5.4 \%$ & $100 \%$ \\
& & & & & & \\
\hline
\end{tabular}

Source: Own study

Irrespective of age, the studied respondents support the most the strategies which are based on independent living and temporarily relying on the assistance of other people, preferably the help of the loved ones. This model is the most popular and indicates a reference, in planning one's own old age or in experiencing one's current old age, to a sense of connection with one's surroundings and loved ones, based on a network of social contacts, ties and affiliations linked above all to one's own living environment and family.

In addition to age, it was assumed that gender could be a factor influencing the choice of one of the proposed strategies. As in the case of age, gender does not correlate with the choice of living arrangement strategy in old age. This means that regardless of gender, respondents favoured the strategy of living in their own flat and using temporary help, preferably provided by relatives and friends. The detailed data distribution is presented in the summary table 3 below.

Table 3. Way of organising life in old age, according to gender in $\%$

\begin{tabular}{|c|c|c|c|c|c|c|c|}
\hline \multicolumn{8}{|c|}{ Does the following way of organising life in old age meet the needs of older people? } \\
\hline \multicolumn{8}{|c|}{ living in your own home and using temporary assistance from people close to you - family, friends, neighbours } \\
\hline man & $1.4 \%$ & $6.8 \%$ & $31.3 \%$ & $39.6 \%$ & $14.6 \%$ & $6.2 \%$ & $100 \%$ \\
\hline \multicolumn{8}{|c|}{ living in their own home with the help of a third person, such as a carer for an elderly person } \\
\hline man & $3.3 \%$ & $9.3 \%$ & $31.1 \%$ & $40.0 \%$ & $10.1 \%$ & $6.2 \%$ & $100.0 \%$ \\
\hline woman & $1.2 \%$ & $9.4 \%$ & $34.2 \%$ & $38.4 \%$ & $12.3 \%$ & $4.6 \%$ & $1.2 \%$ \\
\hline \multicolumn{8}{|c|}{ sharing a flat with children, grandchildren or extended family } \\
\hline man & $4.5 \%$ & $12.2 \%$ & $27.2 \%$ & $32.6 \%$ & $16.5 \%$ & $7.0 \%$ & $100.0 \%$ \\
\hline woman & $3.3 \%$ & $10.4 \%$ & $29.4 \%$ & $34.7 \%$ & $14.2 \%$ & $8.1 \%$ & $100 \%$ \\
\hline \multicolumn{8}{|c|}{ living in their own flat with the support of day care centres } \\
\hline man & $7.0 \%$ & $22.1 \%$ & $36.1 \%$ & $22.1 \%$ & $4.9 \%$ & $7.8 \%$ & $100 \%$ \\
\hline woman & $10.0 \%$ & $17.7 \%$ & $35.3 \%$ & $23.8 \%$ & $5.2 \%$ & $8.1 \%$ & $100 \%$ \\
\hline \multicolumn{8}{|c|}{ living together with other older people, e.g. in a nursing home, a retirement home } \\
\hline man & $3.7 \%$ & $15.1 \%$ & $41.4 \%$ & $24.1 \%$ & $5.6 \%$ & $10.1 \%$ & $100 \%$ \\
\hline woman & $3.1 \%$ & $15.2 \%$ & $38.8 \%$ & $29.6 \%$ & $6.7 \%$ & $6.7 \%$ & $100 \%$ \\
\hline
\end{tabular}

Source: Own study 


\section{ENTREPRENEURSHIP AND SUSTAINABILITY ISSUES}

ISSN 2345-0282 (online) http://jssidoi.org/jesi/

2021 Volume 8 Number 4 (June)

http://doi.org/10.9770/jesi.2021.8.4(25)

\section{Doscussion and Conclusions}

The study aimed to determine the relationship between sociodemographic factors such as age and gender, among others, and the choice of strategies for organizing life in old age when some problems arise. Human life changes with age both under the influence of changes occurring in the body (Goto, 2015; Paskaleva, Tufkova 2017) and under the influence of social opinion, which often perpetuates the sad stereotype of old age (Martin-Matthews, 2000). The course of aging is greatly affected by negative experiences, such as the loss of loved ones, the departure of children or bad contacts with them, deteriorating material situation, a fear of illness and infirmity, a sense of loneliness. States of depression are also caused by chronic illnesses and ailments (Jolanki, 2004.)

There is an inherent risk of disease and disability associated with normal physiological ageing. However, people who take care of their physical health and avoid risky behaviours are more likely to live healthy into old age (Rowe, Kahn, 1987). Healthy ageing refers to the absence of chronic conditions, relative freedom from physical and functional limitations (Rogers, 1995), and if this is coupled with active engagement in life, it provides the opportunity for successful ageing (Rowe, Kahn, 1997). However, not all healthy seniors age successfully, and conversely, many of those who experience illness and disability may age successfully (Sarkisian, Hays, Mangione, 2002). According to research, more important than illness and disability may be the ability to physically and mentally adapt to the limitations of age (von Faber et al., 2001; Betlej et al., 2021), cope with disability, illness and maintain social engagement (Jang, Mortimer, Haley, Graves, 2004).

The presented study was designed to cover a nationwide sample of adult Poles aged 15 and over, which strengthens its validity with respect to population characteristics such as age, gender. The results clearly indicated the essential role of the residential environment and maintaining social ties with family and friends, close neighbours, as an element counteracting social exclusion. The presented results harmonize with previous studies according to which the most important problems of elderly people include loneliness, illness, disability, living in poverty, feeling useless (Paskaleva, Tufkova 2017). All these problems point to the possibility of social exclusion and marginalisation of older people as a collective, exemplified by their gradual elimination from active professional and social life when they cross the retirement age (Adamczyk 2017a).

Remaining in one's own place of residence as well as maintaining close contact with loved ones is one of the important elements of counteracting the situation of exclusion (Adamczyk, 2015: 3-21; Adamczyk 2017b). Psychosocial old age is a complex of multiple, interrelated social, economic, familial and cultural determinants, whose strength of influence varies both environmentally and individually (Kourkouta L., Monios A., 2015). As can be seen from the conducted analyses, despite the existence of individual differences, there is a common conviction among the respondents regarding the role of the place of residence in old age, as well as the importance of family and friendship ties in this period of life as important elements protecting against a sense of alienation, loneliness (Demers, Robichaud, Gélinas, Noreau, Desrosiers, 2008, 237-238).

The analyses conducted show that the best strategy for organising one's life in old age is the one that will rely heavily on a natural system of social support, referring to the immediate environment. It is therefore possible to propose a scheme showing an elderly person in a network of overlapping relationships. This diagram (Figure 3) distinguishes how important the different support systems and accompanying networks of relationships are for an older person 


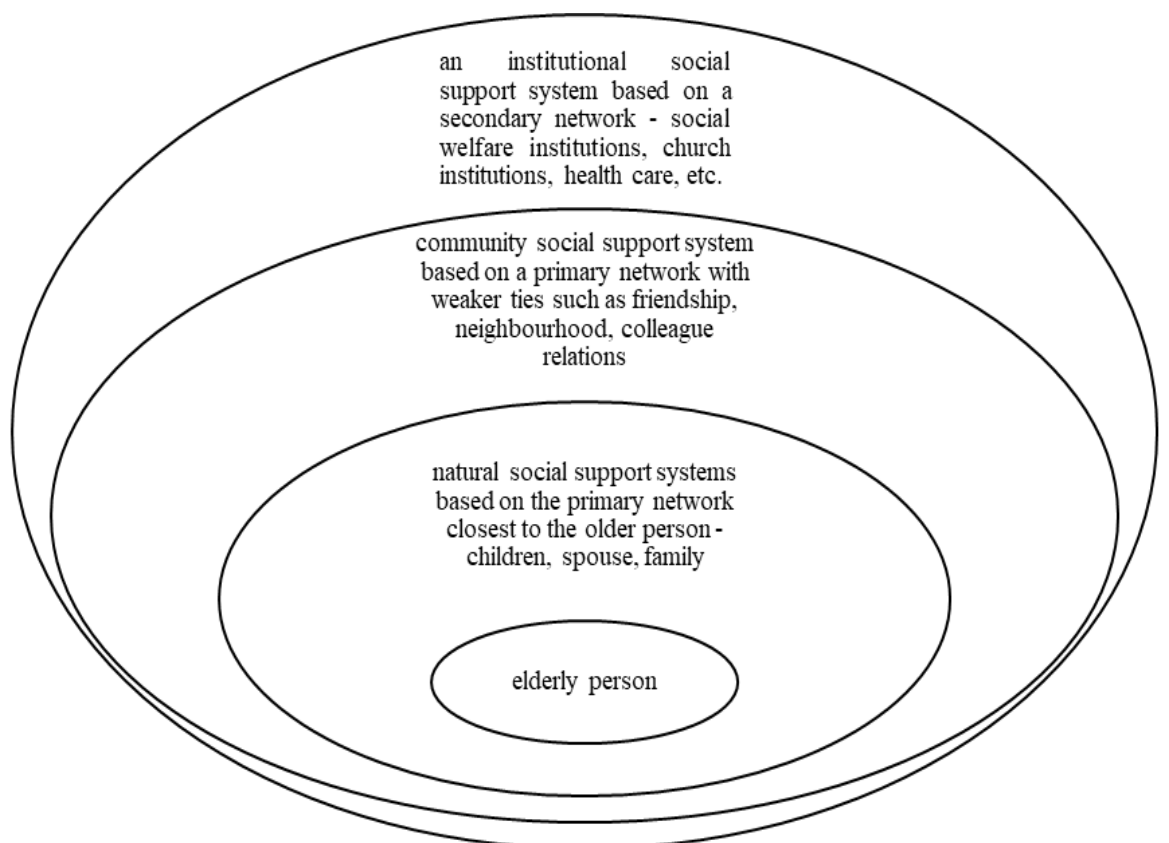

Figure 3. Diagram of the strength of relationship between an older person and their environment and the type of social support system used in strategies of organising life in old age

Source: Own study.

Very important in counteracting social exclusion of older people is anticipating future events while acknowledging the possibility of the unexpected (Fisher, Specht, 1999). Internal coping strategies minimise the effects of negative events (Smith, Borchelt, Maier, Jopp, 2002). According to the respondents, positive coping is also facilitated by having social support, mainly based on the system of natural support, which includes the closest environment, i.e. family and friends. Only then do environmental systems gain in importance in the form of selfhelp groups, which are built on shared experiences, or institutional systems such as social care homes.

\section{References}

Adamczyk, M. 2019. Społeczne uwarunkowania pomyślnego starzenia się i aktywnego przygotowania do emerytury= Social determinants of successful ageing and active preparation for retirement. Lublin.

Adamczyk, M.D. 2017a. Modern Forms of Preparation of Retirement - Selected Results of the Erasmus + Project BALL Be Active Through Lifelong Learning. Transformacje Pismo Interdyscyplinarne = Transformations. An interdyscyplinary Journal, 3-4 (94-95), 220229.

Adamczyk, M. 2017b. Active and Healthy Aging as an Element of Social Integration of Older dults, in: Kinal, J.; Guz, (eds. by) Społeczne aspekty zdrowia: wybrane zagadnienia = Social aspects of health: selected issues, 66-77.

Adamczyk, M. 2015. Więzi rodzinne w procesie pozytywnego i aktywnego starzenia się= Family ties in the process of positive and active ageing. Zeszyty Naukowe KUL- Scientific Bulletins of KUL(4), 3-21.

Aspalter, Ch. 2020. Healthy Aging, Encyclopedia of Gerontology and Population Aging, 1-14. http://doi.org/10.1007/978-3-319-69892-2

Avers D. 2020. Aging Demographics and Trends. Guccione's Geriatric Physical Therapy, 17-37. http://doi.org/10.1016/B978-0-323-60912$\underline{8.00002-6}$ 


\section{ENTREPRENEURSHIP AND SUSTAINABILITY ISSUES}

ISSN 2345-0282 (online) http://jssidoi.org/jesi/

2021 Volume 8 Number 4 (June)

http://doi.org/10.9770/jesi.2021.8.4(25)

Baltes, P. B., Baltes, M. M. 1990. Psychological perspectives on successful aging: The model of selective optimization with compensation. In P. B. Baltes \& M. M. Baltes (Eds.), Successful aging: Perspectives from the behavioral sciences. Cambridge University Press: 1-34. https://doi.org/10.1017/CBO9780511665684.003

Betlej, A., Kačerauskas, T. 2021. Creative Urban Sustainability: the case of Lublin. Sustainability, 13 (7), 4072, 115. https://doi.org/10.3390/su13074072

Betlej, A. 2019. Społeczeństwo sieciowe- potencjały zmian i ambiwalentne efekty= Network society- potentials for change and ambivalent effects. Lublin.

Betlej, A. 2017. Peril and Promise of Internet Technology for Future Social Order. In: Zacher, L. W. (ed. by). Technology, Society and Sustainability. Selected Concepts, Issues and Cases. Springer: 117-128.

Błędowski, P. Szatur -Jaworska (eds.). 2017. System wsparcia osób starszych w środowisku zamieszkania -przegląd sytuacji, propozycja modelu $=$ Support system for the elderly in a residential environment - overview of the situation, proposal for a model. Varsaw.

Błędowski, P., Szatur -Jaworska, B., Szwed-Lewandowska, Z., Kubicki, P. 2012. Raport na temat sytuacji osób starszych w Polsce= Report on the situation of older people in Poland. Varsaw.

Brunton, R.J., Quartly-Scott G. 2015. Do We Fear Ageing? A Multidimensional Approach to Ageing Anxiety. Educational Gerontology, 41(11), 786-799. 150527100153004, http://doi.org/10.1080/03601277.2015.1050870

Čižo, E., Lavrinenko, O., Ignatjeva, S., Danileviča, A., Tvaronavičienè, M. 2020. Financial development and its impact on economic growth (the case of Latvia), Journal of Security and Sustainability Issues, 10(2), 465-476.

Daly, M., Silver, H. 2009. Social Exclusion and Social Capital: A Comparison and Critique. Theory and Society, 37(6), 537-566. http://doi.org/10.1007/s11186-008-9062-4

Demers L., Robichaud L., Gélinas I., Noreau L., Desrosiers J. 2009. Coping Strategies and Social Participation in Older Adults. Gerontology, 55(2), 233-239. http://doi.org/10.1159/000181170

European Commission. 2007. The Social Situation In the European Union 2007. Social Cohesion through Equal Opportunities, https://ec.europa.eu/eurostat/documents/3217494/5716873/KE-AG-08-001-EN.PDF.pdf/0d2bdb68-1565-4347-9806-

$\underline{311 \mathrm{e} 99 \mathrm{~b} 37554 ? \mathrm{t}=1414774915000}$

European Commission. 2008. The Social Situation in the European Union 2008. New Insights into Social Inclusion. https://ec.europa.eu/eurostat/documents/3217494/5715792/KE-AG-09-001-EN.PDF/7997829a-3882-4a63-ae57-07be88cd31a7

European Commission. 2009. The Social Situation in the European 2009. https://ec.europa.eu/eurostat/documents/3217494/5722057/KE-AG-10-001-EN.PDF/4198f7a7-44b0-47bf-a877-eb65388a5430

European Commission. 2020. Social Situation Monitor - Research findings 2020. file:///C:/Users/PRACOW 1/AppData/Local/Temp/KE02-21-043-EN-N.pdf

Fedulova, I., Ivanova, V., Atyukova, O., Nosov, V. 2019. Inclusive Education as a Basis for Sustainable Development of Society. Journal of Social Studies Education Research, 10(3), 118-135.

Fernández-Ballesteros, R. 2010. The concept of 'ageing well' in ten Latin American and European countries. European countries. Ageing and Society, 30(01), 41-56. http://doi.org/10.1017/S0144686X09008587

Fisher, B.J., Specht, D.K. 1999. Successful aging and creativity in later life. Journal of Aging Studies, 13, 457-472.

Garfein, A.J., Herzog, A., Robust, R. 1995. Aging among the Young-Old, Old-Old, and Oldest-Old, The Journals of Gerontology: Series B. $50 \mathrm{~B}(2), 77-87$.

Goto, S. 2015. The Biological Mechanisms of Aging: A Historical and Critical Overview. In: Mori N., Mook-Jung I. (eds) Aging Mechanisms. Springer, Tokyo: 3-27. https://doi.org/10.1007/978-4-431-55763-0_1

Hellström, Y., Andersson, M., Hallberg, I. R. 2004. Quality of life among older people in Sweden receiving help from informal and/or formal helpers at home or in special ac-commodation. Journal of Medical Science, 12(6), 504-516. 


\section{ENTREPRENEURSHIP AND SUSTAINABILITY ISSUES}

ISSN 2345-0282 (online) http://jssidoi.org/jesi/

2021 Volume 8 Number 4 (June)

http://doi.org/10.9770/jesi.2021.8.4(25)

Hickey, S., du Toit, A. 2007. Adverse Incorporation, Social Exclusion and Chronic Poverty. Working Paper 81. Chronic Poverty Research Centre, University of Manchester, Manchester. https://www.chronicpoverty.org/uploads/publication_files/WP81_Hickey_duToit.pdf

Jang, Y., Mortimer, J.A., Haley, W. E., Graves, A.R.B. 2004. The role of social engagement in life satisfaction: Its significance among older individuals with disease and disability. Journal of Applied Gerontology, 23, 266-278.

Jolanki, O. 2004. Moral argumentation in talk about health and old age. Health: An Interdisciplinary Journal for the Social Study of Health, Illness and Medicine, 8, 483-503.

Kourkouta, L., Monios, A. 2015. Psychosocial Issues in Elderly. Progress in Health Sciences, 5(1), 232-237.

Lankauskiené, T., Tvaronavičienè, M. 2012. Security and sustainable development: approaches and dimensions in the globalization context. Journal of security and sustainability issues, 1(4), 287-297

Levinson, D.J. 1978. The seasons of a man's life. Knopf. New York.

Levinson, D. J. 1959. Role, personality, and social structure in the organizational setting. The Journal of Abnormal and Social Psychology, (58), 170-180.

Levinson, D. J. 1977. The mid-life transition: A period in adult psychosocial development. Journal for the Study of Interpersonal Processes, (40), 99-112.

Martin-Matthews, A. 2000. Intergenerational caregiving: How apocalyptic and dominant demographies frame the questions and shape the answers. In E. Gee\& G. Gutman (Eds.), Overselling population aging: Apocalyptic demography, intergenerational challenges, and social policy. Don Mills: Oxford University Press: 64-79.

OECD. 2013. A Good Life in Old Age? Monitoring and Improving Quality in Long-Term Care. https://www.oecd.org/els/healthsystems/PolicyBrief-Good-Life-in-Old-Age.pdf

OECD. 2021. Demography and Population $\quad$ Population https://stats.oecd.org/Index.aspx?DataSetCode=ALFS POP LABOUR

Paskaleva, D., Tufkova, S. 2017. Social and Medical Problems of the Elderly. Journal of Gerontology and Geriatric Research, 6(2-5), 431. http://10.4172/2167-7182.1000431

Publications Office of the EU. 1989. 89/457/EEC: Council Decision of 18 July Establishing a medium-term Community action programme concerning the economic and social integration of the economically and socially less privileged groups in socjety. Official Journal L 224 , 02/08/1989, 10-14.

Ribeiro, M., Silva Borges, M., Cristina, T., Ferreira de Araujo C., Santos Souz M. 2017. Coping strategies used by the elderly regarding aging and death: an integrative review. Revista Brasileira de Geriatria e Gerontologia, 20(6), 866-877. http://doi.org/10.1590/1981$\underline{22562017020.170083}$

Rogers, R.G. 1995. Sociodemographic characteristics of long-lived and healthy individuals. Population and Development Review, 21, 3358.

Rowe, J.W., Kahn, R.L. 1987. Human aging: Usual and successful. Science, 237, 143-149.

Rowe, J.W., Kahn, R.L. 1997. Successful aging. Gerontologist, 37, 433-440.

Rysz-Kowalczyk, B. 2001. Leksykon Polityki Społecznej= Lexicon of Social Policy.Varsaw.

Sarkisian, C.A., Hays, R.D., Mangione, C.M. 2002. Do older adults expect to age successfully? The association between expectations regarding aging and beliefs regarding healthcare seeking among older adults. Journal of the American Geriatrics Society, 50, $1837-1843$.

Sęk, H., Cieślak, R. 2004. Wsparcie społeczne - sposoby definiowania, rodzaje i źródła wsparcia, wybrane koncepcje teoretyczne = Social support - ways of defining, types and sources of support, selected theoretical concepts. [in:] H. Sęk, R. Cieślak (eds.). Wsparcie społeczne, stres i zdrowie $=$ Social support, stress and health. Varsaw, 11-28. 


\section{ENTREPRENEURSHIP AND SUSTAINABILITY ISSUES}

ISSN 2345-0282 (online) http://jssidoi.org/jesi/

2021 Volume 8 Number 4 (June)

http://doi.org/10.9770/jesi.2021.8.4(25)

Silver H. 2019. Social Exclusion, The Wiley Blackwell Encyclopedia of Urban and Regional Studies. Edited by Anthony Orum, JohnWiley \& Sons Ltd: 1-7. http://doi.org/10.1002/9781118568446.eurs0486

Silver, H. 1995. Reconceptualising social disadvantage: three paradigms of social exclusion. In: Rodgers G, Gore C, Figueiredo JB (eds) Social exclusion: rhetoric, reality, responses. International Labour Organization, Geneva: 57-80.

Silver, H. 1994. Social exclusion and social solidarity: three paradigms. Int Inst Labour Stud Geneva, 133, 531-578.

Simmel G. 2006. Obcy= Stranger, in: G. Simmel, Most i drzwi: wybór esejów= The bridge and the door: a selection of essays, Varsaw, 204-212.

Smirnov A. , Lavrinenko O., Ohotina A., Shmarlouskaya H., Betlej, A. 2019. Assessment of Convergence Processes of Social-Economic Security Indicators in Latvian Municipalities. Journal of Security and Sustainability Issues, 9(2): 663-674. http://doi.org/10.9770/jssi.2019.9.2(23)

Smith, J., Borchelt, M., Maier, H., Jopp, D. 2002. Health and well-being in the young old and oldest old. Journal of Social Issues, 58, 715732 .

von Faber, M., Bootsma-van der Wiel, A., van Exel, E., Gussekloo, J., Lagaay, A.M., van Dongen, E., et al. 2001. Successful aging in the oldest old: Who can be characterized as successfully aged? Archives of Internal Medicine, 161, 2694-2700.

WHO. 2015. World report on ageing and health 2015. https://www.who.int/ageing/events/world-report-2015-launch/en/

Monika ADAMCZYK is an associate professor of Social Sciences in the Field of Sociology. An employee of the Institute of Sociological Sciences of the John Paul II Catholic University of Lublin (Poland). Author of Books: Social Determination of Successful Ageing and Active Preparation for Retirement (2019), Discovering the Dynamic Third Age (edit.) (2016), Oldness Between Tradition and Modernity (edit.) (2016), Actively Towards Retirement (2015), Introduction to Social Capital Theory (2013) and many papers and expert opinions. ORCID ID: https://orcid.org/0000-0002-1331-6026

Copyright (C) 2021 by author(s) and VsI Entrepreneurship and Sustainability Center This work is licensed under the Creative Commons Attribution International License (CC BY). http://creativecommons.org/licenses/by/4.0/

c) (i) Open Access 